\title{
Weed Management in Nectarines 1
}

\author{
Jeffrey G. Williamson²
}

The following table contains information on chemical weed control for nectarines grown in Florida. Always read and follow all label directions carefully and exactly when applying any pesticide. Soil types and possible crop injury from herbicides vary greatly throughout Florida. Do not apply a herbicide to an inappropriate soil type even if the herbicide is labeled for that crop. See Table 1.

1. This document is HS92, one of a series of the Horticultural Sciences Department, Florida Cooperative Extension Service, Institute of Food and Agricultural Sciences, University of Florida. Original publication date: 1994. Revised: November, 2007. Please visit the EDIS Web site at http://edis.ifas.ufl.edu.

2. Jeffrey G. Williamson, professor, Horticultural Sciences Department, Cooperative Extension Service, Institute of Food and Agricultural Sciences, University of Florida, Gainesville, FL 32611.

The Institute of Food and Agricultural Sciences (IFAS) is an Equal Opportunity Institution authorized to provide research, educational information and other services only to individuals and institutions that function with non-discrimination with respect to race, creed, color, religion, age, disability, sex, sexual orientation, marital status, national origin, political opinions or affiliations. U.S. Department of Agriculture, Cooperative Extension Service, University of Florida, IFAS, Florida A. \& M. University Cooperative Extension Program, and Boards of County Commissioners Cooperating. Larry Arrington, Dean 
Table 1. Chemical weed control in nectarines.

\begin{tabular}{|l|c|l|}
\hline \multicolumn{1}{|c|}{$\begin{array}{c}\text { Pre-emergence } \\
\text { (Trade name) }\end{array}$} & $\begin{array}{c}\text { Pounds active } \\
\text { ingredient per acre }\end{array}$ & \multicolumn{1}{|c|}{ Time of application } \\
\hline $\begin{array}{l}\text { Oryzalin } \\
\text { (Oryzalin or Surflan) 4AS }\end{array}$ & 2 to 4 & $\begin{array}{l}\text { Allow soil to settle around newly panted trees } \\
\text { before application. Apply before annual weeds } \\
\text { emerge. }\end{array}$ \\
\hline
\end{tabular}

Weeds Controlled and Remarks: Annual grasses and broadleaf weeds. Only 1 application per year.

Existing vegetation should be tilled prior to application or destroyed by a contact herbicide. A single $1 / 2$ to

1 inch rainfall or sprinkler irrigation is needed to move the herbicide into the zone of weed seed

germination.

\begin{tabular}{|l|l|l|}
\hline $\begin{array}{l}\text { Oxyfluorfen } \\
\text { (Goal 2 XL or OxiFlo) 2EC } \\
\text { (GoalTender) 4E }\end{array}$ & $\begin{array}{l}\text { Apply to dormant trees until just before buds } \\
\text { begin to swell. Do not apply when foliage or fruit } \\
\text { are present. }\end{array}$ \\
\hline
\end{tabular}

Weeds Controlled and Remarks: Avoid direct contact with crop plants. Controls annual broadleaf and some grass weeds. May be tank mixed with Certain other pre and post-emergence herbicides (see label). Apply only to healthy trees.

\begin{tabular}{|l|l|l}
\hline $\begin{array}{l}\text { Pendimethalin } \\
\text { (Prowl) } \mathrm{H}_{2} \mathrm{O} \text { AS }\end{array}$ & $\begin{array}{l}\text { Do not apply to newly planted trees until soil has } \\
\text { settled around roots. Prowl has a } 60 \text { day } \\
\text { preharvest interval. }\end{array}$ \\
\hline
\end{tabular}

Weeds Controlled and Remarks: Most effective when adequate irrigation or rainfall occurs within 7 days after application. Can be applied with paraquat to control emerged annual weeds.

\begin{tabular}{|l|c|l|}
\hline \multicolumn{1}{|c|}{$\begin{array}{c}\text { Post-emergence } \\
\text { Common Name } \\
\text { (Trade name) }\end{array}$} & $\begin{array}{c}\text { Pounds active } \\
\text { ingredient per acre }\end{array}$ & \multicolumn{1}{|c|}{ Time of application } \\
\hline $\begin{array}{l}\text { Carfentrazone-ethyl } \\
\text { (Aim) 2EC }\end{array}$ & 0.008 to 0.031 & $\begin{array}{l}\text { Apply when weeds are at the 2-3 leaf stage for } \\
\text { best results. Do not apply within 7 days of } \\
\text { harvest. }\end{array}$ \\
\hline
\end{tabular}

Weeds Controlled and Remarks: Controls certain broadleaf weeds. Use a minimum spray volume of 20 gpa. Do not allow spray to contact green bark or desirable fruit, flowers, or foliage. If spray contacts fruit or foliage, spotting and leaf necrosis can occur. Use a nonionic surfactant or crop oil (see label).

\begin{tabular}{|l|l|l|}
\hline $\begin{array}{l}\text { Fluazifop-butyl } \\
\text { (Fusilade DX) 2 EC }\end{array}$ & $\begin{array}{l}\text { 0.125 to 0.38 } \\
\text { stage (refer to product label). }\end{array}$ \\
\hline
\end{tabular}

Weeds Controlled and Remarks: Certain annual and perennial grasses. Use with a crop oil or nonionic surfactant (see label). May be used for site preparation. Do not harvest within 14 days after application. Do not use more than 72 fluid ounces of formulation per acre per season. Do not graze animals on any treated area. Does not control nutsedges. Avoid contact of spray with crop foliage.

\begin{tabular}{|l|l|l|}
\hline $\begin{array}{l}\text { Glyphosate } \\
\text { (Various) }\end{array}$ & 1 & $\begin{array}{l}\text { Do not apply within } 17 \text { days of harvest. See label } \\
\text { for further information. }\end{array}$ \\
\hline
\end{tabular}

Weeds Controlled and Remarks: Post emergence activity only. Damages all green tissue contacted. Use wiper equipment only. Do not allow contact with foliage, green bark, exposed roots, and other desirable vegetation. See label for restrictions on application equipment. 
Table 1. Chemical weed control in nectarines.

\begin{tabular}{|c|c|c|}
\hline $\begin{array}{l}\text { Common Name } \\
\text { (Trade name) }\end{array}$ & $\begin{array}{l}\text { Pounds active } \\
\text { ingredient per acre }\end{array}$ & Time of application \\
\hline $\begin{array}{l}\text { Paraquat } \\
\text { (Various) }\end{array}$ & 0.66 to 1 & $\begin{array}{l}\text { Apply to weeds when succulent and new growth } \\
\text { is } 1-6 " \text { high. }\end{array}$ \\
\hline \multicolumn{3}{|c|}{$\begin{array}{l}\text { Weeds Controlled and Remarks: Controls most annual grasses and broadleaf weeds. Perennial weeds } \\
\text { are desiccated. Use a non-ionic surfactant (see label). Do not allow spray to contact green stems, fruit or } \\
\text { foliage. Do not spray under windy conditions. Use a shield near young trees. Do not graze on treated } \\
\text { areas. May be tank mixed with certain pre-emergence herbicides. }\end{array}$} \\
\hline $\begin{array}{l}\text { Sethoxydim } \\
\text { (Poast) } 1.5 \mathrm{EC}\end{array}$ & 0.19 to 0.47 & $\begin{array}{l}\text { Apply to actively growing grasses. Do not apply } \\
\text { within } 25 \text { days of harvest. }\end{array}$ \\
\hline \multicolumn{3}{|c|}{$\begin{array}{l}\text { Weeds Controlled and Remarks: For control of most annual and perennial grasses. Rate depends on } \\
\text { type of grass to be controlled. See label for information on additives that increase herbicidal activity. } \\
\text { Multiple applications may be needed to control perennial grasses. Do not apply more than } 5.0 \text { pts. of } \\
\text { Poast per acre per year. Does not control nutsedges. }\end{array}$} \\
\hline
\end{tabular}

